(C) Мельник Ю. Б., Прокопенко Ю. О., Стаднік А. В., 2015. Мельник Юрій Борисович, Прокопенко Юрій Олексійович, Стаднік Анатолій Володимирович

Національна академія Національної гвардії України

\title{
МОЖЛИВОСТІ ПЕДАГОГІЧНОЇ ЛОГІСТИКИ I НОВІ НЕЙРОБІОЛОГІЧНІ ПІДХОДИ
}

Розглянуто педагогічну логістику як окремий науковий напрям. Проаналізовано наукові публікації та сучасні дослідження 3 педагогічної логістики. Розкрито проблеми педагогічної логістики та можливості використання нейробіологічного підходу.

Ключові слова: педагогічна логістика, інформаційно-освітній простір, інформаційна система, нейробіологічний підхід.

Педагогічна логістика оформилася як окремий науковий напрям на початку першого десятиліття цього століття. Понятійнотермінологічний апарат цього напряму ще формується, сьогодні він грунтується на поняттях запозичених у наукових галузях як: педагогіка (освіта, педагогічна система, педагогічна технологія та ін.), психологія (мотивація, установка, дія тощо), економіка (логістика, аналіз, облік та ін.), менеджмент (організація, управління тощо).

Аналіз сучасних наукових публікацій та досліджень вказує, що сьогодні ще немає чіткого розуміння сутність цього поняття. Майже єдиним і найбільш поширенім є визначення «педагогічна логістика» за E. M. Goldratt, 2012. Який під педагогічною логістикою (англ. educational logistics) розуміє - піддисципліну логістики, яка займається менеджментом (управлінням) педагогічних потоків, виходячи 3 принципів логістики та принципу простоти реальних систем [1]. Ю. В. Крупнов використовує інший термін - «освітня логістика», яку він визначає як науку і техніку організації та співорганізації освітніх функцій (позицій) і процесів 3 точки зору підвищення ефективності освітньої діяльності в цілому [2].

Дослідженню проблем педагогічної логістики присвячені роботи таких науковців, як М. О. Мельникова, В. Л. Лівшиць та інших [3-4]. Аналіз наукових публікацій свідчить, що педагогічна логістика, як новий міждисциплінарний науковий напрям, стає затребуваною в різних освітніх галузях.

Наприклад, військовий аспект цієї проблеми розглядає О. М. Маслій [5]. У своїй роботі автор пропонує метод військової педагогічної логістики для створення i оптимізації сучасного 
інформаційно-освітнього середовища ВВНЗ. Наводить основні логістичні показники і аналізує їх роль у такому процесі. Тенденції, що складаються в галузі військової професійної діяльності та системі вищої військової освіти, а також перспективи їх розвитку, які вимагають якісного відновлення не тільки змісту, стандартизації і педагогічного супроводу вищої військової освіти, але й формування принципово нового інформаційно-освітнього середовища вищого військового навчального закладу.

Найбільш актуальною проблемою педагогічної логістики $є$ визнання існування потоку знань та інтелекту. Цей потік включає в себе такі ланки як виробництво знань, розвиток інтелекту, видалення застарілих та поширення нових знань в освітньому просторі. Слід зазначити, що потік навчання складається 3 двох розділів простору: шкільного та вищого професійного. Основна проблема в цьому потоці - створення єдиного інформаційно-освітнього простору. Для вищої освіти ця проблема вирішується в рамках Болонського процесу, але для загальноосвітніх шкіл ця проблема залишається актуальної, як i зв'язку між цими розділами простору.

Для оптимізації методів навчання використовуються найбільш придатні в конкретних умовах освітні та психологічні технології. Це наочно представлено при вивченні інформаційного потоку, який працює за принципами інформаційної логістики. 3'єднує весь інформаційно-освітній простір в єдину систему. Інформаційний потік дозволяє здійснювати управління як макрооб'єктами, так i мікрооб'єктами, тобто окремими об'єктами (учнями, студентами, курсантами), які в цьому процесі виступають як суб'єктивні об'єкти! Це не лінгвістичний парадокс, а педагогічна реальність.

Педагогічна психологія традиційно бере участь в цьому потоці навчання. Останнім часом посилилася тенденція психологізації загальноосвітніх та вищих навчальних закладів. На психологів вищої школи покладається завдання психолого-педагогічного супроводу навчального процесу, розвитку і виховання студентів/курсантів, а на викладачів - навчання, формування у них певних компетентностей. За сучасними уявленнями психологічний потік (пренатальная и перинатальна психологія) починається ще до народження дитини. У зв'язку 3 цим зростає роль нейропедагогіки, нових знань про функціональний розвиток мозку людини, нових стратегій експериментального дослідження активного, осмисленого ставлення особистості до діяльності, нових педагогічних та психологічних технологій. I тому нейробіологічні та нейрофізіологічні технології набувають важливого значення в розумінні педагогічної логістики.

У якості основного закону педагогічної логістики необхідно визначити існування галузі знань - носія для більшості знань, який 
використовується в освітньому просторі. Як носій знань виступає нейробіологія та нейрофізіологія. Саме в цих дисциплінах знаходимо такі суттєві ознаки як ієрархічність організації, логічність побудови тощо.

Отже, використовуючи закони нейробіології як наукової дисципліни нам представляється можливим вивчення будь-якого нового знання 3 перспективою організації цих знань в єдину інформаційну систему.

Таким чином, педагогічна логістика виступає як міждисциплінарний спосіб організації діяльності, що передбачає взаємодію у вивченні одного і того ж об'єкта представниками різних дисциплін. Серед яких особливе місце в методології дослідження, на наш погляд, має посісти нейробіологічний підхід.

\section{Література}

1. Педагогическая логистика / Словари и энциклопедии на Академике [Электронный ресурс] / Режим доступа : http://dic.academic.ru/dic.nsf/ruwiki/175667 - Название с титул. экрана.

2. Крупнов Ю. В. Управление качеством образования и образовательная аналитика [Электронный ресурс] / Ю. В. Крупнов. Режим доступа : http://spasem-shkolu.p-rossii.ru/8/249_1.shtml. Название с титул. экрана.

3. Мельников М. О. Освітня логістика / М. О. Мельников. Миллион, 2005. - № 12. -273 с.

4. Лівшиць В. Л. Педагогічна логістика / В. Л. Лівшиць // Сб. Полісветіе. -Кохтла-Ярве, 2007. - № 1. - С. 72-79.

5. Маслій О. М. Особливості створення сучасного інформаційного освітнього середовища у вищому військовому навчальному закладі / О.М. Маслій // Збірник наукових праць Хмельницького інституту соціальних технологій Університету "Україна". - 2013. - № 1. - С. 140-144.

\section{Юрий Мельник, Юрий Прокопенко, Анатолий Стадник. Возможности педагогической логистики и новые нейробиологические подходы.}

Рассмотрена педагогическая логистика как отдельное научное направление. Проанализированы научные публикации и современные исследования по педагогической логистике. Раскрыты проблемы педагогической логистики и возможности использования нейробиологического подхода.

Ключевые слова: педагогическая логистика, информационнообразовательное пространство, информационная система, нейробиологический подход. 
Yuriy Melnyk, Yuriy Prokopenko, Anatoly Stadnik. Logistics educational opportunities and new neurobiological approaches.

We consider teaching logistics as a separate scientific field. Analyzed scientific publications and current research on teaching logistics. It solved the problem of teaching logistics and feasibility of the neurobiological approach.

Key words: pedagogical logistics, information and educational space, information system, neurobiological approach.

Стаття надійшла до редакційної колегії 01.09.2015

УДК 316.74+613.67-057.875::355.23

(C) Мельник Ю. Б., Свячена С. М., 2015.

Мельник Юрій Борисович

Національна академія Національної гвардії України

Свячена Світлана Михайлівна

Харківська гімназія № 12

\section{ФОРМУВАННЯ КУЛЬТУРИ ЗДОРОВ'Я СТУДЕНТІВ У ВНЗ}

Висвітлено проблему формування культури здоров'я у студентів. Виявлено особливості формування культури здоров'я студентів у вищих навчальних закладах. Запропоновано принципи формування культури здоров'я студентів у вищих навчальних закладах. Введено до наукового обігу поняття «культура здоров'я студента».

Ключові слова: культура здоров'я, принципи формування культури здоров'я, культура здоров'я студента.

Актуальність проблеми формування культури здоров'я зумовлена самою природою цього питання, оскільки здоров'я потребує не лише піклування, а і культивування. Через це поняття здоров'я часто-густо вживається разом зі словами збереження та зміцнення. Саме в такому контексті поняття здоров'я набуває суттєвого значення, оскільки за цих умов відбувається розвиток важливих особистісних якостей, на противагу ним - деградація, хвороба, смерть. Тому формування культури здоров'я є важливим питанням для людини будь-якої сфери діяльності.

Meта статmi - розкрити проблему формування культури здоров'я студентів у вищих навчальних закладах (далі - ВН3); визначити принципи формування культури здоров'я студентів у ВНЗ, ввести до наукового обігу поняття «культура здоров'я студента».

Зміни, що відбуваються у освітній галузі в зв'язку 3 ii реформуванням, ставлять перед педагогічною наукою цілу низку 